\title{
KONSTITUSI SEBAGAI TOLAK UKUR EKSISTENSI NEGARA HUKUM MODERN
}

\author{
Oleh : \\ Indah Sari \\ Dosen Tetap Fakultas Hukum Universitas Dirgantara Marsekal Suryadarma dan \\ aktif di LKBH FH Universitas Dirgantara Marsekal Suryadarma serta Anggota Asosiasi Dosen Indonesia (ADI) \\ Email : Indah.alrif@gmail.com
}

\begin{abstract}
Constitution is a basic and principle regulation which govern a state through a written law (like Undangundang Dasar) or unwritten law (like convention). Every citizen and every state officer should conform to the constitution as a guidance of their act in a country. A constitution reflects a modern and supreme state of law that measure some acknowledgment and protection of human rights, in which freedom, equality, transparency, justice and control of power principles should be delivered. We can administer, by the secondition, a welfare state that would deliver prosperity and order for every citizen.
\end{abstract}

Keywords : constitution, state, state of law, modern state of law.

\begin{abstract}
Abstrak
Konstitusi merupakan hukum dasar dan hukum yang paling tertinggi dalam suatu negara baik tertulis (Undang-Undang Dasar) maupun tidak tertulis (Konvensi). Setiap warga negara dan penyelenggara kekuasaan negara harus tunduk kepada konstitusi yang menjadi pegangan dalam kehidupan bernegara. Keberadaan konstitusi sebagai salah satu unsur negara mencerminkan sebuah negara hukum modern karena di dalam konstitusi diatur perlindungan hak-hak asasi warga negara, adanya asas kebebasan, persamaan, keterbukaan, keadilan serta adanya pembatasan terhadap kekuasaan bagi penyelenggara negara. Dengan demikian maka terciptalah kesejahteraan, kemakmuran serta kehidupan yang tertib dan aman bagi setiap warga negara
\end{abstract}

\section{Kata Kunci : Konstitusi, Negara, Negara Hukum, Negara Hukum Modern.}

\section{PENDAHULUAN}

Keberadaan sebuah negara haruslah memenuhi empat unsur sebagai berikut: (1) memenuhi unsur pemerintahan yang berdaulat, (2) wilayah tertentu, (3) rakyat yang hidup teratur sebagai suatu bangsa (nation), dan (4) pengakuan dari negara-negara lain. Hal ini sejalan dengan Konvensi Montevideo pada tahun 1933 yang isinya menyatakan dalam Pasal 1 Montevideo (Pan Amnerican) Convention on Rights and
Duties of States of $1933^{1}$. Pasal tersebut berbunyi: $^{2}$

"The State as a person of international law should possess the following qualifications:

\footnotetext{
${ }^{1}$ Lihat lebih lanjut Pasal 1 Montevideo (Pan American) Convention on Rights and Duties of States of 1933.

${ }^{2}$ Huala Adolf, Aspek-Aspek Negara dalam Hukum Internasional, Cetakan ke-5, KENI, Bandung, 2015.
} 
a) a permanent population (harus ada rakyat yang tetap)

b) a defined territory (harus ada Wilayah dan Daerah yang tetap)

c) a government; and (harus ada pemerintah)

d) a capacity to enter into relations with other States" (Kemampuan untuk Mengadakan Hubungan Dengan Negara Lain)

Dari keempat unsur untuk berdirinya suatu negara ini belumlah cukup menjamin terlaksananya fungsi kenegaraan suatu bangsa kalau belum ada hukum dasar atau hukum yang tertinggi yang mengaturnya. Hukum dasar dan hukum tertinggi yang dimaksud adalah sebuah Konstitusi atau Undang-Undang Dasar (UUD).

Konstitusi merupakan hukum dasar atau hukum yang paling tertinggi dalam suatu negara. Konstitusi bisa berbentuk tertulis yang disebut dengan UndangUndang Dasar (UUD) dan bisa berbentuk tidak tertulis yang disebut dengan Konvensi. Semua peraturan yang berada dibawah konstitusi harus tunduk kepada Konstitusi. Dalam konteks Indonesia Undang-Undang Dasar 1945 menempati urutan teratas dalam Tata Urutan Peraturan Perundang-Undangan di Indonesia. Hal ini tercantum dalam pasal 7 ayat (1) Undang - Undang Nomor 12 Tahun 2011 tentang Pembentukan Peraturan Perundang-undangan. ${ }^{3} \quad$ Berdasarkan ketentuan Undang-Undang ini jenis dan hierarki peraturan perundang undangan Republik Indonesia adalah sebagai berikut:

${ }^{3}$ Lihat lebih lanjut Pasal 7 ayat (1) Undang-Undang Nomor 12 Tahun 2011 Tentang Pembentukan Peraturan Perundang-undangan.
1) UUD Negara Republik Indonesia Tahun 1945;

2) Ketetapan MPR;

3) UU/Perppu;

4) Peraturan Presiden;

5) Peraturan Daerah Provinsi

6) Peraturan Daerah Kabupaten/Kota

Penyelenggara Negara yang menyelenggarakan negara serta warga negara haruslah memegang teguh dan menerapkan pada kehidupan sehari-hari bahwa konstitusi merupakan hukum dasar dan hukum yang paling tertinggi dalam kehidupannya demi terwujudnya ketertiban, keadilan dan ketentraman hidup bermasyarakat.

Untuk memahami hukum dasar suatu negara, belum cukup kalau hanya dilihat pada ketentuan-ketentuan yang terkandung dalam Undang Undang Dasar atau konstitusi saja, tetapi harus dipahami pula aturan-aturan dasar yang muncul dan terpelihara dalam praktek penyelenggaraan negara meskipun tidak tertulis, atau sering dicontohkan dengan "konvensi" ketatanegaraan suatu bangsa. Sebab dengan pemahaman yang demikian inilah "ketertiban" sebagai fungsi utama adanya hukum dapat terealisasikan.

Disamping konstitusi bertujuan untuk menciptakan ketertiban dalam kehidupan benegara dan berbangsa serta untuk memajukan kebahagiaan dan kesejahteraan warga negara ada tujuan yang terpenting lagi dari konstitusi itu sendiri yaitu membentuk sebuah Negara Hukum. Disini hukum menjadi panglima dari kehidupan bernegara. Negara Hukum yang dimaksud dalam penulisan ini adalah Negara Hukum yang modern yaitu negara yang menjamin persamaan, 
kebebasan warga negara dan pengakuan terhadap hak-hak asasi warganegara serta menciptakan kehidupan yang berkeadilan bagi warga negaranya dengan tujuan akhir menciptakan kesejahteraan dan kebahagian hidup warga negara.

Istilah Negara Hukum baru dikenal pada abad ke-19, tetapi konsep Negara Hukum telah lama ada dan berkembang sesuai dengan tuntutan keadaan, sejak zaman plato hingga kini, konsep negara hukum telah banyak mengalami perubahan yang mengilhami para filsuf dan para pakar hukum untuk merumuskan Negara Hukum dalam hal-hal yang harus ada dalam konsep Negara Hukum. Plato dan Aristoteles mengintrodusir negara berdasarkan hukum sebagai negara yang diperintah oleh negara yang adil. Menurut Plato yang dilanjutkan oleh Aristoteles, hukum yang diharapkan adalah hukum yang adil dan dapat memberikan kesejahteraan bagi masyarakat, hukum yang bukan merupakan paksaan dari penguasa, melainkan sesuai dengan kehendak warga negara. Untuk mengatur hukum itu, dibutuhkan konstitusi yang memuat aturan-aturan dalam hidup bernegara. ${ }^{4}$

Immanuel Kant mengartikan Negara Hukum adalah negara hukum formal (negara berada dalam keadaan statis atau hanya formalitas yang biasa disebut dengan negara penjaga malam/Nachtwakestaat). F.J Stahl kalangan ahli hukum Eropa Kontinental memberikan ciri-ciri negara hukum (Rechtsstaat) sebagai berikut: ${ }^{5}$

\footnotetext{
${ }^{4}$ Abdul Hamid, Teori Negara Hukum Modern, Pustaka Setia, Bandung, 2016, hal. 303-304

${ }^{5}$ Ibid, hal, 304
}

1. Pengakuan terhadap Hak Asasi Manusia (HAM)

2. Pemisahan Kekuasaan

3. Pemerintahan berdasarkan UndangUndang

4. Adanya Peradilan Administrasi

Dalam sejarah kelahirannya, perkembangan maupun pelaksanaannya diberbagai negara, konsep negara hukum sangat dipengaruhi dan bahkan tidak dapat dipisahkan dari asas kedaulatan rakyat, asas demokrasi serta asas konstitusional, karena hukum yang hendak ditegakkan yaitu hukum yang bersumber dari aspirasi rakyat, untuk rakyat, dan dibuat oleh rakyat melalui wakilnya yang dipilih secara konstitusional. Dengan demikian elemen penting dan merupakan syarat mutlak negara hukum adalah: asas pengakuan dan perlindungan hak asasi manusia, asas legalitas, asas pembagian kekuasaan, asas peradilan bebas dan tidak memihak, asas kedaulatan rakyat, asas demokrasi dan asas konstitusional. ${ }^{6}$

Berdasarkan uraian diatas maka akhirnya penulis tertarik untuk membahas permasalahan konstitusi dikaitkan dengan fungsinya dalam mewujudkan negara hukum modern dalam sebuah Jurnal Ilmiah sehingga Penulis mengambil judul "KONSTITUSI SEBAGAI TOLAK UKUR EKSISTENSI NEGARA HUKUM MODERN".

Adapun tujuan dalam penulisan ini adalah:

\footnotetext{
${ }^{6}$ Bahder Johan Nasution, Negara Hukum Dan Hak Asasi Manusia, Mandar Maju, Bandung, 2012, hal.51.
} 
1. Untuk mengkaji dan menganalisis bagaimana bentuk hubungan antara konstitusi dan negara kemudian mengkaji lebih dalam lagi sejauhmana konstitusi berfungsi sebagai tolak ukur eksistensi negara hukum modern.

2. Untuk memberikan masukan dan wawasan bagi dosen dan mahasiswa serta bagi praktisi dan pengamat hukum konstitusi sejauhmana hubungan antara konstitusi dan negara serta bagaimana peranan konstitusi menjadi tolak ukur beradaan Negara Hukum Modern.

Dalam penulisan ini penulis memaparkan Sistematika Penulisan sebagai berikut: pertama, Pendahulan, dimana dalam pendahuluan ini penulis menggambarkan garis besar penulisan, termasuk latar belakang, tujuan penulisan, sistematika penulisan serta teori-teori apa serta peraturan-peraturan perundang-undangan apa yang akan penulis pakai untuk menganalisis penulisan ini. Kedua, Permasalahan, adapun permasalahan yang penulis angkat pada penulisan ini adalah bagaimana hubungan antara konstitusi dan negara serta sejauhmana konstitusi berfungsi sebagai tolak ukur eksistensi negara hukum modern. Ketiga, penulis akan menganalisis permasalahan. Disini penulis akan memulai dari teoriteori dari konstitusi, kemudian memakai teori negara hukum, teori negara hukum modern, lalu menganalisis secara langsung bagaimana konsep negara hukum modern. Keempat, Penutup, merupakan kesimpulan dari penulisan ini yaitu bagaimana penulis menjawab dua rumusan permasalahan diatas.

\section{PERMASALAHAN}

1. Bagaimanakah hubungan antara Konstitusi dan Negara?

2. Sejauhmana Konstitusi berfungsi sebagai tolak ukur eksistensi Negara Hukum Modern?

\section{PEMBAHASAN}

\section{A. KONSTITUSI}

\section{Pengertian Konstitusi}

Istilah konstitusi berasal dari "Constituer" (bahasa Perancis) yang berarti membentuk. Pemakaian istilah konstitusi yang dimaksud ialah pembentukan suatu negara atau menyusun dan menyatakan suatu negara. ${ }^{7}$

Dalam khasanah Ilmu Hukum Tata Negara, kita dapat membedakan pengertian mengenai konstitusi, yaitu konstitusi dalam arti luas dan konstitusi dalam arti sempit, serta konstitusi dalam arti formal dan dalam arti material. ${ }^{8}$

Dalam konteks penulisan ini penulis membatasi pengertian konstitusi tersebut pada pengertian yuridis, yakni bahwa konstitusi adalah suatu naskah yang memuat suatu bangunan negara dan sendisendi sistem pemerintahan negara. Apabila pengertian yuridis ini kita pakai maka tidak dapat tidak artinya menyamakan konstitusi dengan Undang-Undang Dasar.

\footnotetext{
${ }^{7}$ Wiryono Projodikoro, Asas-asas Hukum Tata Negara Indonesia, Dian Rakyat, Jakarta, 1989. hal. 10 dikutip dari bukunya Dahlan Thaib, Kedaulatan Rakyat Negara Hukum dan Konstitusi, Liberty, Yogyakarta, hal. 14.

${ }^{8}$ Dahlan Thaib, Kedaulatan Rakyat Negara Hukum dan Konstitusi, Liberty, Yogyakarta, hal. 14.
} 
Konstitusi sebagai naskah tertulis (Undang-Undang Dasar), pada saat ini lebih sesuai dengan paham modern. ${ }^{9}$

Istilah Undang-Undang Dasar merupakah terjemahan istilah yang dalam bahasa Belanda nya "Grondwet", perkataan "wet" diterjemahkan dalam Bahasa Indonesia Undang-Undang, dan "grond" berarti tanah/dasar. ${ }^{10}$

Mengenai perbedaan istilah antara constitution atau konstitusi dengan grondwet (Undang-Undang Dasar) di atas, L.J, Van Apeldoorn telah membedakan secara jelas di antara keduanya, kalau grondwet (UndangUndang Dasar) adalah bagian tertulis dari suatu konstitusi, sedangkan constitution (konstitusi) memuat baik peraturan tertulis maupun peraturan tidak tertulis. Sementara Sri Soemantri M, mengartikan konstitusi sama dengan Undang-Undang Dasar ${ }^{11}$. Penyamaan arti dari keduanya ini sesuai dengan praktek ketatanegaraan disebagian besar negara-negara dunia termasuk Indonesia.

Herman Heller dalam bukunya Verfassunglehre (ajaran tentang konstitusi). Ia membagi konstitusi itu dalam tiga tingkat yaitu: ${ }^{12}$

1). Konstitusi Sebagai Pengertian Sosial Politik

${ }^{9} \mathrm{Ibid}$, hal.14

${ }^{10} \mathrm{Ibid}$, hal.14

${ }^{11}$ Sri Soemantri, Masalah Kedaulatan Rakyat Berdasarkan UUD 1945, Ghalia Indonesia, 1984 dikutip dari Ibid hal. 14-15

${ }^{12}$ Moh. Kusnardi dan Bintan Saragih, Ilmu Negara,

Gaya Media Pratama, Jakarta, 1994, hal. 140-142
Pada pengertian yang pertama ini konstitusi belum merupakan pengertian hukum, ia baru mencerminkan keadaan sosial politik suatu bangsa itu sendiri. Di sini pengertian hukum adalah sekunder, yang primer adalah bangunan-bangunan masyarakat atau political decission. Bangunan-bangunan ini adalah keputusan masyarakat itu sendiri, misalnya siapa yang menjadi kepala suku, pembantu, atau sebagainya.

2). Konstitusi Sebagai Pengertian Hukum (rechtsfervassung)

Pada pengertian kedua ini, keputusan - keputusan masyarakat tadi dijadikan suatu perumusan yang normatif, yang kemudian harus berlaku (gehoren). Pengertian politik diartikan sebagai eine seine yaitu suatu kenyataan yang harus dan diberikan suatu sanksi kalau hal tersebut dilanggar. Dalam hal ini kita bisa mengambil contoh pada tingkat pertama seperti yang telah dikemukakan di atas misalnya sifat tukar-menukar dalam perdagangan kemudian dijadikan jual - beli, sewa menyewa. Dalam bentuk yang kedua ini kemudian mengandung pengertianpengertian hukum (rechtsfervassung). Rechtsfervassung ini tidak selalu tertulis, misalnya hukum adat. Di sini kita melihat apa yang disebut abstraksi (konstruksi), yaitu suatu cara dalam ilmu pengetahuan hukum untuk menarik unsur-unsur hukum dari kenyataan sosial 
yang kemudian dijadikan perumusan-perumusan hukum.

Seperti halnya dengan tukarmenukar tadi, kemudian dijadikan jual-beli (bagian dari hukum perjanjian).

Rechtsfervassung ada juga yang tertulis. Hal ini timbul sebagai pengaruh dari aliran kodifikasi, yaitu yang menghendaki sebagian hukum ditulis dengan maksud untuk :

- Mencapai kesatuan hukum (rechtsieneheid).

- Kesederhanaan hukum (rechtsvereenvoudiging).

- Kepastian hukum (rechtszekerheid)

3). Konstitusi Sebagai Suatu Peraturan Hukum

Pengertian ketiga ini, adalah suatu peraturan hukum yang tertulis. Dengan demikian Undang-undang Dasar adalah salah satu bagian dari konstitusi dan bukan sebagai penyamaan pengertian menurut anggapananggapan sebelumnya. Penyamaan pengertian adalah pendapat yang keliru, dan bila ada penyamaan pengertian maka ini adalah akibat pengaruh dari aliran kodifikasi (aliran modern).

Penyamaan pengertian konstitusi dengan UndangUndang Dasar tidak hanya akibat dari aliran kodifikasi, tetapi jauh sebelumnya sejak Oliver Cromwell menjadi Lord Protektorat tahun 1660, Grundgezetz (Undang-Undang
Dasar) telah disamakan dengan Instruments of Goverment, yaitu pegangan untuk memerintah. Sejak itu timbul identifikasi pengertian Undang-undang Dasar dengan Konstitusi. Tahun 1687 pengertian Konstitusi Cromwell diambil alih oleh Amerika dan dimasukkan ke Prancis pada tahun 1789 oleh Lafayette.

Pengertian Undang-Undang Dasar adalah lebih sempit adalah pengertian konstitusi, demikian menurut Laselle dalam bukunya Uber Verfassungwesen (sifat konstitusi).

Laselle membagi konstitusi dalam dua pengertian yaitu : ${ }^{13}$

1. Konstitusi antara kekuasaan yang terdapat dalam masyarakat (faktor kekuatan rill), misalnya Presiden, Angkatan Bersenjata, partai-partai, pressure group, buruh, tani dan sebagainya.

2. Konstitusi adalah apa yang ditulis di kertas mengenai lembaga-lembaga negara dan prinsip-prinsip memerintah dari suatu negara. Sama dengan paham kodifikasi.

Pengertian lain dari konstitusi diberikan oleh seorang sarjana Jerman bernama Carl Schmitt. Sarjana ini termasuk dalam Mazhab Politik Berlin. Carl Schmitt membahas konstitusi (verfassung) dengan mengemukakan

${ }^{13}$ Ibid, hal. 142 
empat pengertian dari konstitusi yaitu $:^{14}$

1) Konstitusi Dalam Arti Absolut

Konstitusi ini mencakup seluruh keadaan atau struktur dalam negara itu. Negara disebutkan sebagai suatu ikatan dari manusia yang mengorganisir dirinya dalam wilayah tertentu, maka oleh karena itu konstitusi harus pula menentukan segala apa yang ada dalam negara itu. Konstitusi harus menentukan segala macam kerja sama dalam negara. Kalau bentuk kerja sama itu disebutkannya dengan demokratis, maka konstitusi itu dengan sendirinya akan mencegah bentuk-bentuk kerja sama yang tidak demokratis dalam negara tersebut. Dia menentukan segala bentuk kerja sama dalam organisasi negara. Jadi dialah yang menentukan norma formarum.

2) Konstitusi Dalam Arti Relatif

Konstitusi ini mempunyai segi relatif, karena adanya proses relatifering daripada konstitusi tersebut. Proses ini berlangsung disebabkan karena konstitusi itu dianggap sebagai sebuah naskah penting yang sulit untuk diubahubah, dan dengan sendirinya dapat menjamin adanya kepastian hukum, sehingga apa yang termuat di dalamnya terjamin kelanggengannya. Naskah itu kemudian tak hanya memuat hal-hal yang fundamental, akan tetapi

${ }^{14}$ Ibid, hal.142-144. dimasukkan pula hal-hal yang pada suatu saat dianggap penting untuk negara. Dengan dimuatnya hal-hal ini, kemudian konstitusi ini menjadi bersifat relatif dan tidak sematamata bersifat absolut.

3) Konstitusi dalam Arti Positif

Dalam pengertian ini, konstitusi merupakan suatu putusan yang tertinggi daripada rakyat atau orang-orang yang tergabung dalam organisasi yang disebut negara. Ini yang penting bagi kita untuk membicarakan soalsoal sebagai pegangan bagi policy makers.

4) Konstitusi dalam Arti Ideal

Segi ideal ini sebenarnya jika dilihat dalam sejarah, mulamula sekali memang ideal untuk golongan borjuis liberal. Jadi dianggap sebagai suatu gagasan atau cita-cita yang mutlak agar penguasa tidak bertindak sewenang-wenang terhadap rakyatnya dan kemudian paham ini diterima oleh semua negara. Disini konstitusi mengandung arti sebagai wadah yang menampung sesuatu ide yang dicantumkan satu persatu sebagai isi konstitusi sebagaimana dimaksud dalam pengertian konstitusi dalam relatif di atas.

\section{Sifat Konstitusi}

\section{Tertulis dan Tidak tertulis}

Sudah lazim untuk mengadakan pembedaan antara UUD tertulis dan UUD tidak tertulis. Menurut 
C.F Strong ${ }^{15}$ dalam bukunya Modern Political Constitutions dan

Frank Bealey dalam bukunya Element in Political Science pembedaan ini sebenarnya kurang tepat. Oleh karena tidak ada UUD yang seluruhnya tak tertulis, demikian pula tidak ada UUD yang seluruhnya tertulis. Semua UUD umumnya disebut tertulis bila merupakan suatu naskah, sedangkan UUD tidak tertulis tidak merupakan suatu naskah dan banyak dipengaruh oleh tradisi dan konvensi. Oleh karena itu istilah lain untuk UUD tertulis adalah UUD bernaskah (kadang-kadang disebut dengan codified constitution) sedangkan untuk UUD tak tertulis adalah UUD yang tidak bernaskah (non-codified constitution). ${ }^{16}$

Dalam dunia modern, paham yang membedakan tertulis atau tidak tertulis suatu konstitusi sudah hampir tidak ada. Kalau masih ada konstitusi yang tidak tertulis hanya di Inggris. Namun demikian gambaran dari konstitusi ini sudah kabur atau sudah tidak bisa dibuktikan secara pasti, demikian pula sebaliknya kalau dikatakan suatu negara berkonstitusi tertulis dimana ada juga konstitusi tidak tertulis. Misalnya Indonesia banyak hal-hal yang hidup, yang pada suatu waktu menyingkirkan Undang-Undang Dasar sendiri karena lebih hidup dan diterima oleh masyarakat. Konstitusi yang tertulis biasanya disebut dengan

${ }^{15}$ C.F.Strong, Modern Political Constitutions, London Sidgwick and Jackson, 1963 dikutip dari buku Miriam Budiardjo, Dasar-Dasar Ilmu Politik, Edisi Revisi, Gramedia Pustaka Utama, Jakarta, hal.186

${ }^{16}$ Miriam Budiardjo, Dasar-Dasar Ilmu Politik, Edisi

Revisi, Gramedia Pustaka Utama, Jakarta, hal.186
Undang - Undang Dasar. Sedangkan Konstitusi tidak tertulis biasanya disebut dengan Konvensi. ${ }^{17}$

Membedakan secara prinsipal antara konstitusi tertulis (written constitution) dan tidak tertulis (unwritten constitution) adalah tidak tepat. Sebutan konstitusi tidak tertulis hanya dipakai untuk dilawankan dengan Konstitusi Modern yang lazimnya ditulis dalam sebuah naskah atau beberapa naskah. Timbulnya konstitusi tertulis karena pengaruh aliran kodifikasi. Dimana salah satu negara di dunia yang mempunyai konstitusi tidak tertulis adalah negara Inggris, namun prinsip-prinsip yang dicantumkam dalam konstitusi di Inggris dalam undang-undang biasa, seperti Bill of Rights. Dengan demikian, suatu konstitusi disebut tertulis apabila ia ditulis dalam suatu naskah atau beberapa naskah, sedangkan suatu konstitusi tidak tertulis dikarenakan ketentuan-ketentuan yang mengatur suatu pemerintahan tidak tertulis dalam suatu naskah tertentu, melainkan banyak hal diatur dalam konvensi-konvensi atau undang-undang biasa. ${ }^{18}$

\section{Fleksibel atau Rigid}

Fleksibel atau Rigidnya suatu Konstitusi tergantung dari tiga hal yaitu: ${ }^{19}$

\footnotetext{
${ }^{17}$ Moh. Kusnardi, Bintan R, Saragih, Op.Cit, 1994, hal.144.

${ }^{18}$ Jimly Asshiddiqie, Pengantar Ilmu Hukum Tata

Negara, Rajawali Pers, Jakarta, 2017, hal.118.

${ }^{19}$ Lihat lebih lanjut Moh. Kusnardi dan Bintan

Saragih, Op.Cit, 1994, hal.146-149
} 
1. Mudah atau tidak mudah diubah

Mudah atau tidak mudah diubah tergantung pada pasalpasal konstitusi itu sendiri (yuridis formal). Misalnya Undang-Undang Dasar 1945 memberikan kemungkinan mengubah Undang - Undang Dasar sendiri melalui Pasal 37 yang berbunyi: ${ }^{20}$

1) Usul perubahan pasal-pasal Undang-Undang Dasar dapat diagendakan dalam Sidang Majelis Permusyawaratan Rakyat apabila diajukan sekurangkurangnya $1 / 3$ dari jumlah anggota Majelis Permusyawaratan Rakyat.

2) Setiap usul perubahan pasalpasal Undang-Undang Dasar diajukan secara tertulis dan ditunjukkan dengan jelas bagian yang diusulkan untuk diubah beserta alasannya.

3) Untuk mengubah pasal-pasal Undang-Undang Dasar, Sidang Majelis Permusyawaratan Rakyat dihadiri oleh sekurangkurangnya $2 / 3$ dari jumlah anggota Majelis Permusyawaratan Rakyat.

4) Putusan untuk mengubah pasal-pasal Undang-Undang Dasar dilakukan dengan persetujuan sekurangkurangnya lima puluh persen

${ }^{20}$ Lihat lebih lanjut Pasal 37 Undang-Undang Dasar 1945, Sekretariat Jenderal Mahkamah Konstitusi, Jakarta, 2003 ditambah satu anggota dari seluruh anggota Majelis Permusyawaratan Rakyat.

2. Mudah dan tidak dalam menyesuaikan diri dengan perkembangan masyarakat.

Mudah dan tidak dalam dalam menyesuaikan diri tergantung dari isi dan banyaknya pasal-pasal dari konstitusi itu sendiri. Seperti kita ketahui, isi dari konstitusi adalah mengenai garis-garis besar atau yang pokok atau yang dasar tentang kehidupan negara dan masyarakat. Ada negara yang menyangkutkan isinya dalam mengatur hal-hal penting. Misalnya, kedaulatan ditangan rakyat, itu adalah penting dan juga merupakan garis-garis yang pokok atau yang dasar. Jadi kalau konstitusi itu mengatur hal-hal yang pokok, yang dasar, yang merupakan garisgaris besar saja, biasanya pasalnya sedikit saja. Hal-hal yang lain yang penting biarlah diatur oleh peraturan yang lebih rendah. Perubahan-perubahan dari masyarakat tidak perlu menyentuh konstitusi, cukup dengan membuat peraturan yang lebih rendah atau peraturan pelaksanaan. Kalau konstitusi itu mudah menyesuaikan dirinya dengan perkembangan masyarakat disebut dengan flexibel, sedangkan kalau tidak disebut dengan rigid. 
3. Tergantung kekuatan yang nyata, yang ada dalam masyarakat. Suatu konstitusi dikatakan fleksibel atau rigid, juga tergantung dari kekuatan-kekuatan yang terdapat dalam masyarakat negara bersangkutan. Ini adalah pengertian politis. Kekuatan-kekuatan dalam masyarakat itu misalnya Angkatan Bersenjata, Buruh, Tani, Pressure Group, Partai Politik, dan lain sebagainya. Kalau kekuatan-kekuatan dalam masyarakat itu tidak sering berubah maka Undang-Undang Dasar bisa bertahan dan ini disebut rigid. Atau sebaliknya kalau sering berubah, maka Undang-Undang Dasarnya disebut fleksibel.

\section{Fungsi Konstitusi}

Bagi mereka yang memandang negara dari sudut pandang kekuasaan dan menganggapnya sebagai organisasi kekuasaan, UUD dapat dipandang sebagai lembaga atau kumpulan asas yang menetapkan bagaimana kekuasaaan dibagi antara beberapa lembaga kenegaraan, misalnya antara badan legislatif, badan eksekutif dan badan yudikatif. UUD menentukan cara - cara bagaimana pusat-pusat kekuasaan itu melakukan kerjasama dan menyesuaikan diri satu sama lainnya. UUD merekam hubungan-hubungan kekuasaan dalam suatu negara. ${ }^{21}$

${ }^{21}$ Miriam Budiardjo, Op.Cit, 2008, hal.170
Definisi UUD 1945 dari sudut pandang filsafat diberikan oleh Richard S. Key seorang ahli yang lebih kontemporer. Menurut Kay "Maksud diadakannya UUD adalah untuk melakukan aturanaturan yang pasti yang mempengaruhi perilaku manusia dan demikian menjaga agar pemerintahan tetap berjalan dengan baik (The purpose of a constitution is to lay down fixed rules that can affect human conduct and thereby keep government in good order). ${ }^{22}$

Disamping UUD mempunyai status legal yang khusus, ia juga merupakan ungkapan aspirasi, citacita, dan standar-standar moral yang dijunjung tinggi oleh suatu bangsa. Banyak UUD juga mencerminkan dasar-dasar negara serta ideologinya. Sering unsur ideologi dan moralitas ini dijumpai dalam mukadimah suatu UUD. ${ }^{23}$

Konstitusi memiliki fungsi yang dikemukan oleh Jimly Assshiddiqie Guru Besar Hukum Tata Negara yang memperinci sebagai berikut: ${ }^{24}$

1. Fungsi penentu dan pembatasan kekuasaan organ Negara

2. Fungsi pengatur hubungan kekuasaan antar organ Negara

3. Fungsi pengatur hubungan kekuasaan antar organ Negara dengan Warga Negara

22 Seperti dikutip oleh Larry Alexander, ed, Constitutionalism, Philosophical Foundations, Cambridge University Press, Cambridge, 1999, hal.4. Ibid, hal.170

${ }^{23} \mathrm{Ibid}$, hal. 170

${ }^{24}$ Khelda Ayunita, Pengantar Hukum Konstitusi dan Acara Mahkamah Konstitusi, Mitra Wacana Media, Jakarta, 2017, hal. 25. 
4. Fungsi pemberi atau sumber legitimasi terhadap kekuasaan Negara ataupun kegiatan penyelenggaraan kekuasaan Negara

5. Fungsi penyalur atau pengalih kewenangan dari sumber kekuasaan yang asli (dalam demokrasi adalah rakyat) kepada organ Negara.

6. Fungsi simbolik sebagai sarana pemersatu (symbol of unity), sebagai rujukan identitas dan keagungan kebangsaan (identity of nation), serta sebagai center of ceremony.

7. Fungsi sebagai sarana pengendali masyarakat (social control), baik dalam arti sempit yaitu bidang politik dan dalam arti luas mencakup bidang sosial ekonomi.

8. Fungsi sebagai sarana perekayasa dan pembaruan masyarakat (social engineering atau social reform).

\section{Nilai dari Konstitusi}

Karl Laewenstein ${ }^{25}$ memberikan tiga tingkatan nilai pada konstitusi yaitu :

1. Nilai yang bersifat Normatif (keharusan-ein sollen).

Dalam setiap undang-undang dasar ada dua masalah yaitu :

a. Sifat ideal dari undang undang dasar itu (teori).

${ }^{25}$ Moh. Kusnardi dan Hermaily Ibrahim, Pengantar Hukum Tata Negara, Pusat Studi Hukum Tata Negara FH UI, Jakarta, 1983, hal.72 dikutip dari Moh Kusnardi dan Bintan Saragih, Op.Cit, 1994, hal.156-157. b. Bagaimana melaksanakan undang-undang dasar itu (praktek).

Peraturan hukum yang bersifat normatif ialah kalau peraturan hukum itu masih dipatuhi oleh masyarakat, kalau tidak ia merupakan peraturan yang mati (ideal), tidak pernah terwujud. Jadi konstitusi yang bersifat normatif, jika konstitusi itu resmi diterima oleh suatu bangsa dan bagi mereka bukan saja berlaku dalam arti hukum (legal), tetapi juga merupakan kenyataan dalam arti sepenuhnya.

2. Nilai yang bersifat Nominal

Nilai konstitusi yang bersifat nominal ialah kalau konstitusi itu kenyataannya tidak dilaksanakan dan hanya disebutkan namanya saja. Dengan kata lain konstitusi tersebut menurut hukum berlaku, tetapi tidak dilaksanakan sebagaimana mestinya yaitu tidak memiliki kenyataan yang sempurna.

\section{Nilai yang bersifat Semantik}

Nilai konstitusi yang bersifat semantik ialah suatu konstitusi yang dilaksanakan dan diperlakukan dengan penuh, tetapi hanyalah sekedar memberi bentuk (formalization) dari tempat yang telah ada untuk melaksanakan kekuasaan politik. Maksud ensensil dari suatu konstitusi adalah mobilitas kekuasaan yang dinamis untuk mengatur, tetapi 
dalam hal ini dibekukan demi untuk kepentingan pemegang kekuasaan yang sebenarnya.

\section{Tujuan dan Hakikat Konstitusi}

Di kalangan para ahli hukum, pada umumnya dipahami bahwa hukum mempunyai tiga tujuan pokok yaitu: (i) keadilan (justice); (ii) kepastian (certainty atau zekerheid); (iii) kegunaan (utility). Keadilan itu sepadan dengan keseimbangan (balance, mizan) dan kepatutan (equity), serta kewajaran (proportionality). Sedangkan kepastian hukum terkait dengan ketertiban (order) dan ketentraman. Sementara itu, kegunaan diharapkan dapat menjamin bahwa nilai-nilai tersebut akan mewujudkan kedamain hidup bersama $^{26}$

Karena konstitusi itu sendiri merupakan hukum yang dianggap paling tinggi tingkatannya, tujuan konstitusi sebagai hukum yang tertinggi itu juga untuk mencapai dan mewujudkan tujuan yang tertinggi. Tujuan yang dianggap tertinggi adalah (i) keadilan; (ii) ketertiban; dan (iii) perwujudan nilai-nilai ideal seperti kemerdekaan atau kebebasan dan kesejahteraan atau kemakmuran bersama, sebagaimana yang dirumuskan sebagai tujuan oleh para pendiri negara (the founding fathers and mothers). ${ }^{27}$ Sehubungan dengan itulah, beberapa sarjana merumuskan konstitusi itu seperti merumuskan tujuan negara, yaitu negara konstitusional, atau negara

${ }^{26}$ Jimly Asshiddiqie, Op.Cit, 2017, hal.119.

${ }^{27}$ Ibid, 119 berkonstitusi. Menurut J. Barents, ada tiga tujuan negara, yaitu: (i) untuk memelihara ketertiban dan ketentraman; (ii) mempertahankan kekuasaan; dan (iii) mengurus halhal yang berkenaan dengan kepentingan-kepentingan umum $^{28}$ Semeatara itu, Maurice Hauriou menyatakan bahwa tujuan konstitusi adalah untuk menjaga keseimbangan antara: (i) ketertiban (order); (ii) kekuasaan (gezag); (iii) kebebasan (vrijheid). ${ }^{29}$

Kebebasan individu warganegara harus terjamin, tetapi kekuasaan negara juga harus berdiri tegak sehingga tercipta tertib bermasyarakat dan bernegara. Ketertiban itu sendiri terwujud apabila dipertahankan oleh kekuasaan yang efektif dan kebebasan warga negara tetap tidak terganggu. Sementara itu G.S Diponolo merumuskan tujuan konstitusi ke dalam lima kategori yaitu: (i) kekuasaan; (ii) perdamaian, keamanan, dan ketertiban, (iii) kemerdekaan, (iv) keadilan, serta (v) kesejahteraan dan kebahagiaan. ${ }^{30}$

\section{B. NEGARA HUKUM MODERN}

\section{Kedaulatan Hukum}

Kata kedaulatan berasal dari kata sovereignty (bahasa Inggris), souverainete (bahasa Perancis),

28 J. Barents, "De Wetenschap de Politiek, Een Terreinverkenning” (1952), Terjemahan L.M Sitorus, Ilmu Politika: Suatu Perkenalan Lapangan, cet. ke-3, (Jakarta: PT.Pembangunan 1958), hal. 38. Ibid, hal 119

${ }^{29}$ Maurice Hauriou, Precis de Droit Contitutionnel: lihat juga Abu Daud Busro, Ilmu Negara, (Jakarta, Bumi Aksara, 1990), hlm. 99. Ibid, hal.119-120.

${ }^{30}$ G.S. DiponoIo, Ilmu Negara, Jilid I, Jakarta: Balai Pustaka, hal.23, Ibid, 120 
soranus (bahasa Italia). Kata-kata asing tersebut diturunkan dari kata Latin superanus yang berarti "yang tertinggi" (supreme). Sarjana-sarjana dari abad menengah lazim menggunakan pengertian pengertian yang serupa makna dengan istilah superanus itu, yaitu summa potestas atau plenitudo potestatis yang berarti wewenang tertinggi dari suatu kesatuan politik. $^{31}$ Banyak sekali definisi untuk kata itu tetapi "istilah ini selalu berarti otoritas pemerintahan dan hukum"32

Baru pada abad ke-15 kata kedaulatan itu tampil sebagai istilah politik yang banyak dipergunakan terutama oleh sarjana-sarjana Prancis. Sarjanasarjana Prancis inilah yang kemudian mempopularisasi pemakaian kata kedaulatan (souverainete). Menurut Prof. Garner, Beaumanoir dan Loyseau sebagai sarjana-sarjana hukum yang pertama kali menggunakan kata itu dalam abad ke-15. ${ }^{33}$

Dalam kepustakaan Ilmu Negara dikenal adanya bermacammacam teori kedaulatan yaitu: Teori Kedaulatan Tuhan, Teori Kedaulatan Negara, Teori Kedaulatan Rakyat dan Teori Kedaulatan Hukum. Mengenai Teori Kedaulatan Hukum merupakan pertentangan terhadap

31 F. Isjawara, Pengantar Ilmu Politik, Cetakan Kesembilan, Bina Cipta, Jakarta, 1992. hal. 108 dan lihat juga pada bukunya Ni'matul Huda, Ilmu Negara, Rajali Pers, Depok, 2017, hal.169

${ }^{32}$ Francis W.Coker, Souvereignty, Encyclopaedia of Social Sciences, Vol:14, hal. 265 dikutip dari Ibid, hal.169

${ }^{33}$ Ni'matul Huda, Ilmu Negara, Rajawali Pers,

Jakarta, 2017, hal. 169
Teori Kedaulatan Negara yang mengajarkan bahwa negara berada di atas hukum, karena negaralah yang membuat hukum. Teori kedaulatan hukum tidak dapat menerima kekuasaan seseorang atau sekelompok penguasa, membuat hukum berdasarkan kehendak mereka pribadi, kemudian hukum yang dibuatnya itu dikonsepsikan sebagai kehendak negara. Menurut teori kedaulatan hukum, bukan hukum yang ditentukan oleh negara tetapi sebaliknya negara lah yang ditentukan hukum dan karena itu negara adalah produk hukum, jadi negara harus tunduk pada hukum. Mengapa demikian? Secara sederhana jawabannya karena hukum muncul dari kesadaran hukum setiap orang. Tugas negara adalah menjelmakan kesadaran hukum itu dalam bentuk ketentuan hukum positif, berupa peraturan hukum yang dibuat oleh masyarakat sendiri melalui wakilwakilnya di parlemen. ${ }^{34}$

Krabbe menyatakan Kedaulatan Hukum adalah bahwa kedudukan hukum berada di atas negara dan oleh karenanya negara harus tunduk pada hukum. Tunduknya negara terhadap hukum menurut A.M Donner dikatakan sebagai "de doordringing van de staat met het recht" artinya hukum mempunyai kedudukan tertinggi dalam negara. Peperzak (1971:43) menilai, sumber hukum yang berasal dari kesadaran hukum masyarakat tidak lain sebagai kristalisasi moral sehingga setiap

\footnotetext{
${ }^{34}$ Bahder Johan Nasution, Op.Cit, 2012, hal.48
} 
pihak secara moral pula harus mentaati hukum ("hence the feeling that there is amoral duty to obey the law"...). ${ }^{35}$

Inti ajaran teori kedaulatan hukum yang mengajarkan tunduknya negara kepada hukum, membawa konsekuensi bahwa setiap kekuasaan yang ada dalam negara harus tunduk kepada hukum. Jadi hukum merupakan kekuasaan tertinggi dalam negara.

\section{Nilai Penting Konstitusi Dalam Negara}

Bahwa pada kenyataannya tanpa konstitusi negara tidak mungkin terbentuk, maka konstitusi menempati posisi yang sangat krusial dalam kehidupan ketatanegaraan suatu negara. Demikian halnya negara dan konstitusi merupakan lembaga yang tidak dapat dipisahkan satu dengan yang lain. Dr. A. Hamid S. Attamimi, dalam disertasinya berpendapat tentang pentingnya suatu konstitusi atau UndangUndang Dasar adalah sebagai pemberi pegangan dan pemberi batas, sekaligus tentang bagaimana kekuasaan negara harus dijalankan. $^{36}$

Sejalan dengan pemahaman di atas, Struycken dalam bukunya $\mathrm{Het}$ Staatsrecht van Het Koninkrijk der

${ }^{35} \mathrm{Ibid}$, hal.49.

36 A. Hamid S. Attamimi, Peranan Keputusan Presiden Republik Indonesia Dalam Penyelenggaraan Pemerintahan Negara, Disertasi, UI Jakarta, hal.125 yang dikutip dari Dahlan Thaib, Jazim Hamidi, Ni'matul Huda,Teori dan Hukum Konstitusi, Edisi Revisi, Rajawali Pers, Jakarta, 2001, hal. 63
Nederlanden menyatakan bahwa Undang-Undang Dasar sebagai konstitusi tertulis merupakan sebuah dokumen formal yang berisi: $^{37}$

1. Hasil perjuangan politik bangsa di waktu yang lampau.

2. Tingkat-tingkat tertinggi perkembangan ketatanegaraan bangsa.

3. Pandangan tokoh-tokoh bangsa yang hendak diwujudkan, baik untuk waktu sekarang maupun untuk masa yang akan datang.

4. Suatu keinginan, dengan mana perkembangan kehidupan ketatanegaraan bangsa hendak dipimpin.

Dari empat materi muatan yang tereduksi dalam konstitusi atau undang-undang di atas, menunjukkan arti pentingnya konstitusi bagi suatu negara. Karena konstitusi menjadi barometer kehidupan bernegara dan berbangsa yang sarat dengan bukti sejarah perjuangan para pendahulu, sekaligus ide-ide dasar yang digariskan oleh the founding fathers, serta memberikan arahan kepada generasi penerus bangsa dalam mengemudikan suatu negara yang mereka pimpin. Semua agenda penting kenegaraan ini telah terkaver dalam konstitusi.

Pada sisi lain, eksistensi suatu "negara" yang diisyaratkan oleh A.G. Pringgodigdo, baru riel-ada kalau memenuhi empat unsur: (1) memenuhi unsur pemerintahan

37 Sri Soemantri, Prosedur dan Sistem Perubahan Konstitusi, Alumni, Bandung, 1987, hal.2 dikutip dari Ibid, hal.64 
yang berdaulat, (2) wilayah tertentu, (3) rakyat yang hidup teratur sebagai suatu bangsa (nation), dan (4) pengakuan dari negara-negara lain. ${ }^{38}$ Dari keempat unsur untuk berdirinya suatu negara ini belumlah cukup menjamin terlaksananya fungsi kenegaraan suatu bangsa kalau belum ada hukum dasar yang mengaturnya. Hukum dasar yang dimaksud adalah sebuah Konstitusi atau Undang-Undang Dasar.

Untuk memahami hukum dasar suatu negara, juga belum cukup kalau hanya dilihat pada ketentuan-ketentuan yang terkandung dalam Undang Undang Dasar atau konstitusi saja, tetapi harus dipahami pula aturan-aturan dasar yang muncul dan terpelihara dalam praktek penyelengaraan negara meskipun tidak tertulis, atau sering dicontohkan dengan "konvensi" ketatanegaraan suatu bangsa. Sebab dengan pemahaman yang demikian inilah "ketertiban" sebagai fungsi utama adanya hukum dapat terealisasikan.

\section{Supremasi Konstitusi Dalam Negara}

Dalam Negara Modern penyelenggara kekuasaan negara dilakukan berdasarkan hukum (droit constitutionil). UndangUndang Dasar atau verfassung oleh Carl Schmit dianggap sebagai keputusan tertinggi. ${ }^{39}$ Sehingga

${ }^{38}$ C.S.T.Kansil, Hukum Antar Tata Pemerintahan, Airlangga, Jakarta, 1986, hal.13 dikutip dari Ibid, hal.65

${ }^{39}$ Ismail Saleh, Demokrasi, Konstitusi, dan Hukum, Depkeh RI, Jakarta, 1998, hal. 18 dikutip dari Ibid, hal. 68 konstitusi mempunyai kedudukan atau derajat supremasi dalam suatu negara. Yang dimaksud dengan supremasi konstitusi yaitu dimana konstitusi mempunyai kedudukan tertinggi dalam tertib hukum suatu negara. ${ }^{40}$

Menurut K.C Wheare dalam bukunya Modern Constitutions memberikan penjelasan yang pada intinya kedudukan konstitusi dalam suatu negara bisa dipandang dari dua aspek, yaitu aspek hukum dan aspek moral.

Pertama, konstitusi dilihat dari aspek hukum mempunyai derajat tertinggi (supremasi). Dasar pertimbangan supremasi konstitusi itu adalah karena beberapa hal:

a. Konstitusi dibuat oleh Badan Pembuat Undang-Undang atau lembaga-lembaga

b. Konstitusi dibuat atas nama rakyat, berasal dari rakyat, kekuatan berlakunya dijamin oleh rakyat, dan ia harus dilaksanakan langsung kepada masyarakat untuk kepentingan mereka.

c. Dilihat dari sudut hukum yang sempit yaitu dari proses pembuatannnya, konstitusi ditetapkan oleh lembaga atau badan yang diakui keabsahannya.

Superioritas konstitusi mempunyai daya ikat bukan saja bagi rakyat/warga negara tetapi termasuk juga bagi para penguasa

${ }^{40}$ Parlin M. Mangungsong, Konnvensi Ketatanegaraan Sebagai Salah Satu Sarana Perubahan UUD, Alumni, Bandung, 1992, hal. 22 dikutip dari Ibid, hal. 68 
dan bagi badan pembuat konstitusi itu sendiri,

Kedua, jika konstitusi dilihat dari aspek moral landasan fundamental, maka konstitusi berada dibawahnya. Dengan kata lain, konstitusi tidak boleh bertentangann dengan nilai-nilai universal dari etika moral. Oleh karena itu dilihat dari constitusional phyloshofi, apabila aturan konstitusi bertentangan dengan etika moral, maka seharusnya konstitusi dikesampingkan. ${ }^{41}$

Menurut K.C.Wheare, dengan menempatkan konstitusi pada kedukannya yang tinggi (supreme) ada semacam jaminan bahwa:

"konstitusi itu akan diperhatikan dan ditaati dan menjamin agar konstitusi tidak akan dirusak dan diubah begitu saja secara sembarangan. Perubahannya harus dilakukan secara hikmat, penuh kesungguhan dan pertimbangan yang mendalam. Agar maksud ini dapat dilaksanakan dengan baik maka perubahannya pada umumnya mensyaratkan adanya suatu proses dan prosedur yang khusus dan istimewa". ${ }^{42}$

\section{Konsep Negara Hukum Modern}

Untuk memahami apa yang dimaksud dengan negara hukum dalam arti yang sesungguhnya, terlebih dahulu harus dipahami pengertian negara hukum itu

${ }^{41}$ K.C. Wheare, Modern Constitutions, London Oxford University Press, Third Impression, New York and Toronto, 1975, hal. 62-63 dikutip dari bukunya Dahlan Thaib, Jazim Hamidi dan Ni'matul Huda,

Teori dan Hukum Konstitusi, Edisi Revisi, Rajawali

Press, Jakarta, hal.68-69.

${ }^{42}$ Ibid, hal. 73. sendiri, sebab tanpa memahami terlebih dahulu pengertian negara hukum maka sulit untuk mendeskripsikan apa yang dimaksud dengan neagara hukum tersebut. Wiryono Projodikoro (1971:10), memberikan pengertian negara hukum sebagai negara dimana para penguasa atau pemerintah sebagai penyelenggara negara terikat pada peraturanperaturan hukum yang berlaku. Muhammad Yamin (1952:74) mendefinisikan negara hukum sebagai suatu negara yang menjalankan pemerintahan yang tidak menurut kemauan orangorang yang memegang kekuasaan, melainkan menurut aturan yang tertulis yang dibuat oleh badanbadan perwakilan rakyat yang terbentuk secara sah yang sesuai denagn asas "the laws and not menshall govern". Sudargo Gautama (1973:73-74) bahwa paham negara hukum berasal dari ajaran kedaulatan hukum, ia memberi pengertian tentang negara hukum sebagai negara dimana alatalat negaranya tunduk pada aturan hukum. Joeniarto (1968:8) memberikan definisi atau pengertian tentang negara hukum sebagai negara dimana tindakan penguasanya harus dibatasi oleh hukum yang berlaku. Sementara Soedirman Kartohadiprojo (1953:13) mendefinisikan negara hukum sebagai negara dimana nasib dan kemerdekaan orangorang di dalamnya dijamin sebaikbaiknya oleh hukum. ${ }^{43}$ 
Sehingga kita dapat menyatakan prinsip dasar negara hukum adalah melakukan perlindungan bagi rakyatnya terhadap tindak pemerintah sewenang-wenang dan perlindungan terhadap hak-hak asasi manusia. Dan jika dicari inti dari pengertian negara hukum sebenarnya adalah tunduknya penguasa terhadap hukum sebagai sebuah esensi negara hukum. Esensi negara hukum yang demikian menitikberatkan pada tunduknya pemegang kekuasaan negara pada hukum.

Negara hukum sering disebut juga dengan konsep Rechtsstaat yang menyatakan adanya pengakuan dan perlindungan terhadap hak asasi manusia yang bertumpu pada prinsip kebebasan dan persamaan. Secara teoritik pengakuan dan perlindungan terhadap hak asasi manusia dalam konsep Rechtsstaat dapat dilihat dari kriteria: ${ }^{44}$

1. Adanya Undang-Undang Dasar yang akan memberikan jaminan secara konstitusional bagi warga terhadap asas kebebasan dan persamaan.

2. Adanya pemisahan kekuasaan bertujuan untuk menghindari dari penumpukan kekuasaan dalam satu tangan, karena penumpukan kekuasaan ini sangat cendrung mengarah pada penyalahgunaan kekuasaan yang berarti pemerkosaan terhadap kebebasan dan persamaan.
3. Adanya pembuatan UndangUndang yang dikaitkan dengan parlemen, dimaksudkan untuk menjamin bahwa hukum yang dibuat adalah atas kehendak rakyat, dengan demikian hukum tersebut tidak akam memperkosa hak-hak rakyat, dan apabila dikaitkan dengan asas mayoritas, kehendak rakyat diartikan sebagai kehendak golongan mayoritas.

4. Adanya prinsip "wetmatig bestuur" agar tindak pemerintahan didasarkan pada ketentuan Undang-Undang dan tidak memperkosa kebebasan dan persamaan.

Berdasarkan pada prinsipprinsip liberal dan prinsip-prinsip demokratis tersebut maka Rechtsstaat memiliki ciri-ciri pokok sebagai berikut (hadjon, 1987:76): ${ }^{45}$

a. Adanya Undang-Undang Dasar atau Konstitusi yang memuat ketentuan tertulis tentang hubungan antara penguasa dan rakyat.

b. Adanya pembagian kekuasaan negara yang meliputi kekuasaan pembuat Undang-Undang yang ada pada parlemen, kekuasaan kehakiman yang bebas yang tidak hanya menangani sengketa, antara individu dan rakyat tetapi juga antara penguasa dan rakyat, dan pemerintahan yang mendasarkan tindakannya pada Undang-Undang.

${ }^{44}$ Ibid, hal.6

${ }^{45}$ Ibid, hal. 19 
c. Diakui dan dilindunginya hakhak rakyat (Vrijheidsrechten van de burger)

Sedangkan Sudarto Gautama (1973:8-10) menyebutkan ciri Rechtsstaat antara lain: ${ }^{46}$

a. Terdapat pembatasan kekuasaan negara kepada perorangan, pembatasan itu dilakukan oleh hukum

b. Pelanggaran atas hak-hak individu hanya boleh atas dasar aturan hukum (asas legalitas)

c. Adanya perlindungan hak asasi manusia (hak - hak kodrati)

d. Adanya pemisahan kekuasaan

e. Badan Peradilan yang tidak memihak.

Menurut Stahl (Ridwan H.R.,2007:30), unsur-unsur negara hukum (Rechtsstaat) adalah sebagai berikut: ${ }^{47}$

1. perlindungan hak-hak asasi manusia

2. pemisahan atau pembagian kekuasaan untuk menjamin hakhak itu

3. pemerintahan berdasarkan peraturan perundang-undangan

4. peradilan administrasi dalam perselisihan

5. supremasi aturan-aturan hukum (supremacy of the law)

6. tidak adanya kekuasaan sewenang-wenang (absence of arbitrary power)

7. kedudukan yang sama dalam menghadapi hukum (equality before of the law)
8. terjaminnya hak-hak manusia oleh undang-undang dan keputusan pengadilan.

Sedangakan

menurut

Aristoteles ada tiga unsur suatu pemerintahan dikatakan konstitusional, yaitu: ${ }^{48}$

1. pemerintah yang dilaksanakan oleh kepentingan umum

2. pemerintah yang dilaksanakan menurut hukum yang berdasarkan ketentuan umum, bukan hukum yang dibuat secara sewenang-wenang yang mengesampingkan konvensi dan konstitusi.

3. pemerintah yang dilaksanakan atas kehendak rakyat, bukan berupa paksaan tekanan yang dilaksanakan pemerintah despotik.

Menurut Miriam Budiardjo (1982:19), ciri pemerintahan demokratis di bawah rule of law adalah sebagai berikut: ${ }^{49}$

1. adanya proteksi konstitusional

2. pengadilan yang bebas dan tidak memihak

3. kebebasan untuk menyatakan pendapat

4. pemilihan umum yang bebas

5. kebebasan berserikat / berorganisasi dan beroposisi

6. pendidikan civil (kewarganegaraan)

7. pengakuan dan perlindungan hak-hak asasi manusia yang mengandung persamaan dalam bidang politik, hukum sosial, ekonomi dan kebudayaan.

${ }^{46}$ Ibid, hal.20.

${ }^{47}$ Abdul Hamid, Op.Cit, Pustaka Setia , Bandung,

${ }^{48} \mathrm{Ibid}$, hal.306

2016, hal.307

${ }^{49} \mathrm{Ibid}$, hal.307 
8. peradilan yang bebas dan tidak memihak serta tidak dipengaruhi oleh suatu kekuasaan atau kekuatan apa pun.

9. legalitas dalam arti hukum dalam segala bentuknya.

Mengutip pandangan Konsep Hukum Modern dalam pandangan Max Weber (Salman dkk, 2012:9092) memiliki ciri-ciri sebagai berikut: ${ }^{50}$

a. aturan-aturan hukum memiliki kualitas normatif yang umum dan abstrak

b. hukum modern adalah hukum positif, hasil keputusan yang diambil secara sadar

c. hukum modern diperkuat oleh kekuasaan yang memaksa dari negara dalam bentuk sanksi yang diberikan dengan sengaja, dikaitkan dengan aturan hukum yang dapat berlaku melalui pengadilan, jika terjadi pelanggaran hukum.

d. hukum modern adalah aturanaturannya sistematis, prinsipnya, konsepnya, dan doktrinnya serta bagian hukum prosedural dan hukum material yang beragam.

e. hukum modern adalah sekuler, substansinya terpisah dari pertimbangan keagamaan dan etis

Sehingga kita dapat menyatakan pada konteks Negara Hukum Modern yang membawa nilai-nilai demokrasi, konstitusi memiliki fungsi untuk membatasi kekuasaan pemerintah agar pemerintah tidak berlaku sewenang-wenang dalam menyelenggarakan negara dan pemerintahannya sehingga diharapkan hak-hak warganegara akan lebih terlindungi. Pembatasan-pembatasan tindakan pemerintah tercermin dalam Undang-Undang Dasar atau Konstitusi.

\section{PENUTUP}

Pada bagian penutup penulis akan menyimpulkan dua rumusan masalah yang penulis angkat dalam tulisan ini, pertama bagaimana hubungan antara konstitusi dan negara. Adapun hubungan antara konstitusi dan negara dapatlah penulis simpulkan sebagai berikut:

1. Negara adalah produk hukum (muncul dari kesadaran setiap orang). Hukumlah yang mengatur negara dan tentu negara harus tunduk kepada hukum terutama hukum yang tertinggi dalam suatu negara yaitu konstitusi.

2. Salah satu unsur dalam negara yang mutlak harus ada adalah Konstitusi. Antara konstitusi dan negara tidaklah dapat dipisahkan Konstitusilah yang mengatur hubungan negara dan warganegaranya. Konstitusi akan mencegah terjadinya pemusatan kekuasaan dan tindakan sewenangwenang negara terhadap warganegaranya. Penyelenggara kekuasaaan negara harus didasarkan pada konstitusi.

3. Negara harus tunduk pada konstitusi karena kududukan konstitusi lebih tinggi dari negara dan otomatis setiap kekuasaan

${ }^{50} \mathrm{Ibid}$, hal.313 
harus tunduk kepada konstitusi. Sehingga kedaulatan yang paling tertinggi dalam suatu negara adalah kedaulatan hukum bukan kedaulatan negara.

4. Negara mempunyai legalitas dan sebagai alat pemaksa konstitusi harus ditaati oleh setiap warga negara. Siapun yang tidak mentaati konstitusi, negara mempunyai wewenang dan daya paksa untuk memberikan sanksi sesuai dengan peraturan yang berlaku.

Untuk menjawab rumusan masalah kedua yaitu; sejauhmana konstitusi berfungsi sebagai tolak ukur eksistensi negara hukum modern akan penulis paparan sebagai berikut:

Dalam sebuah Negara Hukum Modern keberadaan sebuah konstitusi sebagai hukum dasar dan hukum tertinggi dalam suatu negara mutlak harus ada dikarenakan baik penyelenggara negara dalam menyelenggarakan kekuasaannya maupun warga negaranya harus tunduk terhadap hukum. Pada negara yang menganut konstitusi sebagai hukum yang paling tertinggi, penundukan terhadap konstitusi oleh seluruh warga negara menempatkan konstitusi sebagai pegangan utama bagaimana kekuasaan negara harus dijalankan dan bagaimana menjaga keseimbangan kehidupan warga negara dan negara, inilah yang membedakan dengan negara yang menganut konsep monarki bahkan negara yang menganut konsep tirani. Konstitusi membawa modernisasi dalam penyelenggaraan negara dengan menjunjung tinggi nilai-nilai demokrasi seperti aspirasi warga negara, hak-hak asasi manusia, asas kebebasan, asas persamaan, asas keadilan dan asas pemisahan kekuasaan sehingga kekuasaan tidak berpusat pada satu tangan (absolute)

Akhirnya penulis dapat menyimpulkan bahwa sesungguhnya konteks negara hukum yang modern pasti memegang prinsip-prinsip demokrasi yang didasarkan pada konstitusi yang mana gunanya adalah untuk membatasi kekuasaan pemerintah agar pemerintah tidak berlaku sewenang-wenang dalam menyelenggarakan negara sehingga diharapkan hak-hak warganegara akan lebih terlindungi dan terpenuhi. Pada akhirnya tercapailah kehidupan yang adil, makmur dan sejahtera bagi seluruh warga negara sehingga terciptalah negara yang tertib, aman dan damai.

\section{DAFTAR PUSTAKA}

Buku

Adolf, Huala, Aspek-Aspek Negara Dalam Hukum Internasional, Cetakan ke-5, KENI, Bandung, 2015

Asshiddiqie, Jimly, Pengantar Ilmu Hukum

Tata Negara, Rajawali Pers, Jakarta, 2017

Ayunita, Khelda, Pengantar Hukum

Konstitusi Dan Acara Mahkamah Konstitusi, Mitra Wacana Media, 2017

Budiardjo, Miriam, Dasar-Dasar Ilmu Politik, Edisi Revisi, Gramedia Pustaka Utama. Jakarta, 2008

Hamid, Abdul, Teori Negara Hukum

Modern, Pustaka Setia, Bandung, 2016

Huda, Ni'matul, Ilmu Negara, Rajawali

Pers, Jakarta, 201 
Konstitusi Sebagai Tolak Ukur Eksistensi Negara Hukum Modern

Iswara, F, Pengantar Ilmu Politik, Bina

Cipta, Jakarta, 1992

Kusnardi, Moh dan R.Saragih, Bintan,

Ilmu Negara, Gaya Media Pratama,

Jakarta, 1994

Nasution, Bahder Johan, Negara Hukum

Dan Hak Asasi Manusia, Mandar Maju,

Bandung, 2012

Thaib, Dahlan; Hamidi, Jazim; Huda

Ni'matul, Teori Dan Hukum Konstitusi,

Edisi Revisi, Rajawali Pers, Jakarta, 2001

Thaib, Dahlan, Kedaulatan Rakyat Negara

Hukum Dan Konstitusi, Liberty,

Yogyakarta, 2000

\section{Peraturan Perundang-undangan}

Undang-Undang Dasar Negara Republik

Indonesia Tahun 1945, Sekretariat

Jenderal Mahkamah Konstitusi, Jakarta, 2003.

Undang-Undang Nomor 12 Tahun 2011

Tentang Pembentukan Peraturan

Perundang-undangan

Montevideo (Pan American) Convention

on Rights and Duties of States of 1933 